\title{
SOBRE O PODER DA CRIAÇÃO: PARENTESCO E OUTRAS RELAÇÕES AWÁ-GUAJÁ*
}

Uirá Garcia

Onde quer que haja Alguma Coisa, Alguma Outra Coisa virá ficar a seu lado.

Provérbio Igbo, citado por Chinua Achebe

"Eu vou ficar com você!" (A iku ta ni pyry), "Fique logo comigo!" (Hariruku apãj), foi o que disse a jovem Ipokaxi'ĩa ao velho Xiramú. A jovem estava com 12 anos e "gostou" (maparã) ${ }^{1}$ dele, que já era um quinquagenário. A esposa anterior de Xiramú deixara-o, levando quatro dos seus cinco filhos, mudando-se para outra aldeia a fim de viver junto a um jovem de quem havia "gostado", "se enamorado". Não é nenhuma raridade, e as mulheres awá-guajá, que se casam ainda tão novinhas - muitas vezes com homens bem mais velhos - se cansam de tanta "velharada" (wyxa'atekera) e deliberadamente trocam seus alquebrados esposos por homens jovens que, assim formulam, serão melhores companheiros: jovens, bonitos, menos rabugentos, mais produtivos na caça, dentre outros motivos que a "mulherada" (awa wahykera) defende. Desde a separação em 2012, Xiramú andava cabisbaixo em sua aldeia. ${ }^{2}$ Havia conseguido se unir a uma menina que rapidamente o abandonou, alegando ser ele "velho demais" para se casar com ela (ixa'a kera, "muito crescido"). E voltou a ficar sozinho. Até que a pequena Ipokaxi'ĩa lhe fez a feliz proposta: "Fica logo comigo!" (hariruku apãj), em uma tradução literal, "você pode ficar logo perto de mim?". Quando o pai da jovem relatou tais episódios, disse-me: Xiramú nixa'á ta, "(minha filha) será criada por Xiramú". Nixa'á ("criar"), pensado para a relação conjugal, é o mesmo termo utilizado por pais que criam filhos, e mulheres que criam filhotes de animais na aldeia.

O episódio é recente, ocorreu em 2013, e fazia pelo menos sete anos que eu frequentava as aldeias awá. Já tinha familiaridade com os temas referentes à conjugalidade, o cálculo oblíquo envolvido nas alianças matrimoniais, e já havia chegado a uma ou duas conclusões sobre o que podemos definir como "casamento" para essas pessoas; reconhecia os "arranjos" envolvendo grandes diferenças etárias, com a preferência por cônjuges de gerações distantes, além 
da ideia de que, como sabemos de outros casos amazônicos, uma esposa deve ser "criada" enquanto tal. No entanto, não estávamos mais no universo dos "casamentos arranjados" e, além disso, se o velho Xiramú estava em vias de se casar com a menina Ipokaxi'ĩa, foi porque sua esposa anterior, Jauxiká (de 28 anos, e mãe de seus cinco filhos), largara-o por um rapaz de 14 anos. Durante um período fora de casa, Jauxiká argumentou querer viver com o jovem Takwarí na aldeia Juriti, sugerindo que Xiramú voltasse a viver em sua aldeia de origem, sem ela ou os filhos. Foi esta separação que fez com que Xiramú sofresse de tristeza (assim os Awá definiram, kijé) e procurasse por outra esposa.

O casamento de Xiramú com sua ex-mulher foi desfeito para ambos recomeçarem uniões com cônjuges de gerações descendentes. Em uma imagem um tanto forçada, é como se os Guajá não concordassem com dois jovens se casando (muito embora o façam com mais frequência nos dias atuais), tendo que fazê-lo com pessoas de gerações diferentes. Observo não apenas aquilo que Lévi-Strauss (1982 [1967]:404) afirmou ser um "desprezo pela noção de geração", ao comentar um antigo trabalho sobre os Miwok, mas uma preferência radical pelo casamento oblíquo, que nem sempre ocorrerá com a filha da irmã (ZD), como sabemos dos sistemas oblíquo-avunculares (como um paralelo Jê, ver Schroeder 2006:157-160). Os Awá fariam parte daquilo que Viveiros de Castro (2002a:113, nota 8) mencionou espirituosamente como "avunculares sem complexo", ao lado dos Tupinambá, Parakanã e Mondé, em oposição àqueles povos nos quais o casamento avuncular — embora uma possibilidade real - aparece, segundo os etnógrafos, como um desvio das normas, "uma união semilícita, semi-incestuosa", ${ }^{3}$ parte incestuosa, porém "apetitosa", diria Rivière (1969:190-191). ${ }^{4}$ Apesar de o foco deste artigo não ser uma análise sistêmica da aliança awá-guajá, a obliquidade nos casamentos, tal como um leitmotiv, acompanhará todo o texto.

\section{Parentesco}

A produção teórica sobre o "parentesco no contexto amazônico", entendido de maneira ampla como "uma abreviação cômoda para o que, na Amazônia, seria mais bem chamado teoria da relacionalidade generalizada" (Viveiros de Castro 2002c:422), a saber, as formas de aliança, produção de pessoas e coisas, alternativas para um modelo genealogista-terminológico, concebe a afinidade como um símbolo que transcende o parentesco. Tal conceito, complementado pela sua contraparte, a consanguinidade, assume formas variadas que "não só determinariam outros referentes que os nossos, como envolvem outros componentes" (Viveiros de Castro 2002c:407). Talvez, por seu 
caráter demasiadamente formalista e eurocêntrico, os estudos de parentesco tenham passado, durante o final do século XX, por dolorosas críticas, com alguns autores, entre eles David Schneider e sua "crítica cultural", clamando a extinção do campo de estudo, uma vez que este estaria ancorado em interpretações errôneas, análises etnocêntricas, consagrando um objeto de estudo inexistente, um "artefato" manipulado analiticamente pelos antropólogos, uma vez que o parentesco não encontra uma contraparte concreta em nenhuma das sociedades que estudamos (Schneider 1984:196-201; 2004 [1972]:271). Em sua crítica, Schneider problematiza as análises que denomina "simbolistas", que tendem a projetar a "nossa forma de pensar" em sistemas de pensamento completamente diferentes dos "nossos" (Schneider 2011 [1965]:454).

Tais autores, bem como aqueles que fizeram parte da chamada "crítica feminista", encaminharam os estudos para o que Carsten (2000:02) denominou shift away from kinship, esse "afastamento do parentesco", baseado em um julgamento mais amplo referente aos propósitos da empreitada intelectual da antropologia. Como consequência, o trabalho de Marilyn Strathern aparece como uma das grandes contribuições, pois efetivamente o parentesco deixou de "ser tomado como dado" (Strathern 2006 [1988]:386), uma coisa em si, para ser inserido em um circuito de relações mais amplas. Isto aparece tanto em seu trabalho sobre as Terras Altas da Nova-Guiné, no qual a autora atesta como "as relações de parentesco passam a ser matéria de transações, e as pessoas se dedicam a expandi-las da única maneira possível - produzindo 'mais' parentesco", quanto na análise "merográfica" desenvolvida sobre o parentesco euro-americano, em que a noção de "sociedade" e o "parentesco" contemporâneo (inglês, no caso) estão inseridos em "campos sobrepostos" (overlapping fields), em complexas antíteses que embaralham ideias como "natureza e cultura", "público e privado", dentre outras (Strathern 1992:133-136).

O interesse atual demonstrado pela antropologia do parentesco, cuja "homonímia (com a noção euro-americana de parentesco) visa ressaltar as diferenças, a despeito das semelhanças" (Viveiros de Castro 2002c:407), vem produzindo análises menos essencialistas, procurando entender processos de vida, de pessoas que estão associadas entre si, como parentes que "participam intrinsecamente da existência uma das outras" (Sahlins 2011:01). Embora tal "relacionalismo" não esteja completamente ausente das análises clássicas, como lembra Strathern (1995:12; 2006 [1988]:394), as relações de parentesco foram redefinidas a partir de outros tópicos, tais como corpo, pessoa, gênero, e no caso amazônico, da guerra, da predação, do comércio e do xamanismo, em que desde o final da década de 1970 "reconheceu-se a necessidade de se forjar uma linguagem adequada à realidade etnográfica" (Viveiros de Castro 
2002a:106). ${ }^{5}$ A etnologia indígena sul-americana (muitas vezes vista como uma cidadela conservadora fechada em si mesma), através do trabalho de autores preocupados em incorporar nos estudos do parentesco o complexo quadro cosmológico da região, tem definido o parentesco como adágio de uma peça mais ampla, pensando-o, por exemplo, a partir da produção de um "bem viver" (Overing 1999; Gow 1991, 1997) em face do marcado fundo de hostilidade virtual das sociocosmologias da região (Viveiros de Castro 2002c).

\section{A relação em questão}

A partir desta breve introdução podemos questionar: de que outras maneiras os antropólogos conseguem discutir o parentesco em coletivos nos quais tal conceito, assim como nós o concebemos, não está colocado? Como podemos pensar o parentesco, mais especificamente o sistema de aliança em um grupo ameríndio como os Awá-Guajá, quando boa parte do que formulam sobre isso remete a outras esferas que não a do parentesco? Por exemplo, para definirem uma relação conjugal, os Guajá mobilizam elementos diferentes dos envolvidos em nosso próprio sistema, e pensam o casamento como um processo de "criação". Em termos mais diretos, a produção de cônjuges, seja de homens ou mulheres, é coextensiva a outras relações que usualmente escapariam ao campo do parentesco.

No início de minha pesquisa de campo, ao começar a traçar as genealogias, entender os casamentos e colher os termos de parentesco na língua, as pessoas constantemente definiam o fato de maridos e esposas estarem "juntos" (pyry), morando na mesma casa e criando filhos com termos exatamente idênticos àqueles com que explicavam por que as mulheres criam seus xerimbabos; ou por que cada qualidade de mel está relacionada a seres "donos do méis" (Garcia 2010:236-243), ou mesmo por que - a partir de uma sensível percepção etológica - diferentes espécies de animais são muitas vezes encontradas juntas, ou ao menos próximas umas das outras, como se determinado animal andasse junto de outro. Quando o tema do parentesco surgia em minhas indagações, as pessoas lançavam-no para fora do campo conceitual sobre o qual eu estava confortavelmente instalado.

As respostas gravitavam em torno de ideias como nixa'á ("criar para filho", "criar para cônjuge", ou mesmo "fazer crescer"), utilizadas preferencialmente por mulheres. Elas formulavam a seguinte frase: jahá amixa'á

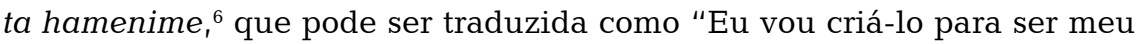
marido", ou literalmente, "Eu vou transformá-lo em marido". Da mesma maneira, um casamento que os pais possam planejar para sua filha é refe- 
rido através da frase máj mãnã, ou seja, "vou mandar/enviar para ele criar (a minha filha)". E um homem à procura de casamento costuma dizer $a$ máj ta harimiriko rame, que pode ser traduzido simplesmente como "Eu vou criá-la como esposa". O sufixo $r$-ame (ou nime, a depender) no final da frase guarda uma função translativa que, como sugere, indica que o nome harimiriko, "minha esposa", ainda será uma esposa, e isto só acontecerá depois que ela sofrer algumas transformações. A tradução literal para esta frase seria, portanto, "eu vou transformá-la em esposa".

Paralelo a isso, os Guajá trazem um conceito de relação revelado pelo verbo rikú (ou rukú, a depender do falante), central em sua socialidade, que orienta a proximidade e a distância entre diferentes seres no mundo, no sentido sociológico da afinidade potencial amazônica. ${ }^{7}$ Trata-se de um processo contínuo de produção de novas relações entre pessoas (assinalando a paternidade e a maternidade, por exemplo) e coisas (produzindo a posse de determinados objetos, por exemplo), encontrando ressonâncias na conhecida ideia de "familiarização" da literatura da etnologia sul-americana (cf. Erikson 1987, 2012; Fausto 2001; Bonilla 2005) ou "maestria" (Fausto 2008; Kohn 2007), envolvendo pessoas, plantas, animais, espíritos em relações que implicam "donos", sendo muitos os exemplos em que isto aparece (ver p.ex.: Bonilla 2005; Cabral 2012; Cesarino 2010; Descola 1986, 2006; Erikson 1987; Fausto 2008; Gallois 1988; Hugh-Jones 1996; Kohn 2007; Lea 2012; Lima 2005; Viveiros de Castro 2002d, dentre outros).

Desta forma, baseado em minha experiência de campo, o artigo visa refletir sobre questões relativas à figura dos donos na Amazônia, propondo um diálogo com um dos aspectos menos explorados do tema, que é a relação destes com a conjugalidade. Argumento que, para os Awá-Guajá, as relações recortadas do universo da "familiarização" e da "maestria" são não apenas coextensivas ao campo do parentesco, como também revelam uma concepção muito particular do que seja a relação conjugal. Apesar de dialogar com a conhecida imagem dos "donos de roça", "donos de animais", "das águas" e outros correspondentes, tomo o conceito de dono aqui como uma imagem-guia (nos termos de Strathern 2006:208), a ser mobilizada em sua definição relacional, pensada tanto para as relações de familiarização quanto para a conjugalidade. A continuidade ontológica entre maestria e casamento - cosmologia e sociologia - para os Awá não remete a uma alegoria simbólica que, por analogia, conecta em termos conjugais humanos e não humanos (tal como um xamã e suas esposas celestes; ou casamentos intraespecíficos mitológicos). Não se trata de uma conjugalidade cosmológica, mas a própria relação de casamento é pensada como uma relação de "criação" (conceito que elaboro a partir da própria etnografia) e, de muitas maneiras, homóloga a outras relações no mundo. 
O que nos dizem os Awá é que há uma íntima relação entre o casamento e a maestria, e isto os levará não a reificar a noção de dono, transportando-a automaticamente para o parentesco, mas parcialmente conectar esta noção a ele (o parentesco), produzindo uma crítica etnográfica a esta mesma noção de dono.

\section{Awá}

"Humanos", como encontramos em tantos povos ameríndios, é a tradução para awá, ${ }^{8}$ funcionando como um "marcador enunciativo" de uma condição de pessoa (Viveiros de Castro 2002b:371), e nos dias de hoje, a depender da aldeia, se autorreferem como "Awá", "Guajá" (um nome que apareceu no contato com o Estado brasileiro) e "Awá-Guajá" (utilizado nos últimos anos), termos que alternarei aqui sem muito controle. Trata-se de um pequeno grupo de caçadores habilidosos, habitantes da porção oriental da Amazônia, e muito pouco conhecidos na literatura etnológica. Não fosse a breve menção de Ballé (1994) e os trabalhos de Forline (1997) — ligado à antropologia ecológica - e Cormier (2003), ainda seriam anônimos no debate da etnologia americanista. Habitantes das bacias dos rios Turiaçu, Gurupi e Mearim, a população atual conta com cerca de 460 pessoas, distribuídas por cinco aldeias em três terras indígenas. ${ }^{9}$ Famosos por não praticarem agricultura, não dominavam qualquer cultivo agrícola, nem mesmo milho ou mandioca. Tal situação vem se modificando ao longo dos últimos 20 anos, com a população mais jovem sendo "ensinada" por funcionários da Funai a cultivar mandioca (basicamente para a produção de farinha), além de outros cultivares.

Andarilhos (watama'a - caçadores/caminhadores), sempre viveram nas cabeceiras dos formadores do Caru, Pindaré e Turiaçu, nos topos e contrafortes das serras do Tiracambu e Desordem, que formam parte do extremo leste amazônico. As "terras altas" (wytyra), lembram os Awá, por estarem distantes dos cursos de rios, forneciam uma posição segura contra encontros indesejados, como com os povos Tenetehara ou os karaí ("não indígenas"), que não conhecem esses caminhos. Mesmo hoje em dia, durante as caçadas, costumam retornar às antigas aldeias e locais de caça situados nas "terras altas" da floresta, mantendo ainda um grande conhecimento a respeito dos caminhos lá existentes (ver Garcia 2012a).

Apesar de contatados e com seus territórios homologados, os Awá vêm experimentando pressões de grileiros, pecuaristas, pequenos agricultores e madeireiros que ocupam as terras indígenas, a última reserva florestal 
do estado do Maranhão. Dada a violência do contexto regional, são hoje protagonistas de matérias de jornais e campanhas internacionais que os classificam, não sem razão, como um dos povos mais ameaçados do mundo. ${ }^{10}$

\section{Criando conjugalidades}

Não cabe aqui discutir os aspectos formais da terminologia de parentesco awá-guajá. ${ }^{11}$ Apenas observaria que o termo reservado à esposa é imirikô, que também se refere à filha de uma irmã (ZD) para ego masculino; e hawajá é o termo dispensado aos afins de sexo oposto, "cunhado" ou "sogro", e para um filho de irmã (ZS). Já uma mulher pode se referir ao seu tio materno (MB) através do termo imẽna, "marido". Como demonstrado em outros trabalhos (Cormier 2006; Garcia 2010) — e de maneira categórica — pode-se dizer que se trata de um sistema oblíquo-avuncular, marcado por equações transgeracionais nas regras de casamento.

Como já adiantei, os Guajá postulam que o casamento entre um homem e uma mulher é uma relação que pode ser ilustrada pelo verbo rikú ou rukú, ${ }^{12}$ cuja tradução mais conhecida é "estar com". Como ocorre com outras línguas da família Tupi-Guarani, o verbo -ikó (ikú na língua guajá) é traduzível por "estar com" ou "estar associado a" (realizando alguma ação, como morar, plantar etc.). ${ }^{13}$ Em seu "Vocabulário do Guarani" (mbya), Dooley, um missionário linguista do SIL (Summer Institute of Linguistics), define -reko como um verbo transitivo, cuja primeira tradução é "ter", sendo que as outras quatro possibilidades de significado, no entanto, referem-se a relações de domesticação e conjugalidade, como "criar (animais)", "plantar", "conduzir (uma pessoa)", e "andar junto" (Dooley 1982). ${ }^{14}$ Isto posto, "criar", "plantar", "conduzir (uma pessoa)", "andar junto (à esposa ou ao marido)", dentre outras definições que podem (ou não) se relacionar a esta, são passíveis de serem exprimidas através da ideia de rikú entre os Awá.

Neste caso, a tradução que gostam de fornecer em português é "criar" e, por isso, por uma questão de estilo e efeito, utilizarei o verbo "criar", sabendo contudo que tal glosa pode não ser necessariamente a melhor. Porém, ao traduzirem tal verbo como "criar" — e não "casar" ou "estar associado a" indicam menos uma falta de compreensão sobre o nosso léxico ${ }^{15}$ do que a sinalização para um outro sistema de ação, uma outra teoria sobre a relação conjugal. Quanto a uma "tradução antropológica", a ideia de rikú se associa a esta forma generalizada de relação na Amazônia, que prescreve relações assimétricas que gravitam em torno do conceito de "donos". De um lado, mestres, donos, controladores - e no caso Awá, pais (F, M) e cônjuges $(\mathrm{W}, \mathrm{H})$ - 
e de outro, animais de caça, animais domésticos, mel (e abelhas), frutos e vegetais - e no caso awá, filhos e cônjuges (novamente). Por exemplo:

1. A relação entre uma mãe e seus filhos é tida como uma relação do tipo rikú. 2. O laço conjugal estabelecido entre um marido e sua esposa é chamado rikú. 3. A relação perfilhada entre humanos e animais domésticos (chamados nimá), filhotes de presas animais caçados e criados na aldeia, é dita rikú.

4. Da mesma forma os objetos. Possuir uma flecha, uma faca, um tecido ou qualquer outra coisa é manter com o objeto uma relação do tipo rikú. No contexto awá-guajá, a ideia de criar é mais significativa para exprimir o controle do que o verbo "possuir". O portador de determinado objeto, ao possuí-lo, o "cria" mais do que o "tem": a'e rikú ("eu o crio"), seria a resposta imediata quando alguém diz estar com algo.

A partir dessas traduções, e fazendo uma brevíssima digressão, é possível relembrar que a domesticação de diversos cultivares para os Achuar é percebida num fundo mais amplo de relações sociais de domesticação (Descola 1986). Da mesma forma, "andar junto com" espíritos auxiliares é condição capital para a atividade xamânica em quase todos os contextos ameríndios, tal como criar animais (capturados), como contraparte da predação (e não só), é uma forma de relação entre humanos e o mundo, difundida em toda a Amazônia (Erikson 1987, 2012; Lea 2012:339-345). Ou ainda, que o cauim Yudjá, mais próximo da carne (por ser um corpo) do que de uma bebida vegetal, é produzido e cuidado por sua dona tal como se cuida (cria) um filho (Lima 2005:299-300), assim como na cosmologia waiãpi, na qual praticamente tudo deve ser criado e afinizado em um ou outro nível (Gallois 1988:122).

Os Awá, portanto, também postulam que boa parte das relações no mundo pode ser pensada como relações deste tipo, sendo o rikú o esquema relacional que as fundamenta. As muitas relações dos povos ameríndios com seus estimados animais de criação — os chamados "xerimbabos" — está bem documentada em parte da bibliografia etnológica, ${ }^{16}$ inclusive entre os Awá-Guajá (Cormier 2003). Não entrarei em detalhes sobre o tema, pois, como já mencionado, ele tem aparecido com certa frequência na literatura etnológica recente. Lembro apenas que, para o caso awá-guajá, a primeira a observar a relação entre as mulheres e os hanimá, "meu animal de criação", foi Cormier (2003), que fez da perfilhação desses pets o tema central de seu trabalho.

Como um contraponto, evoco a noção de iwa elaborada pelos Yudjá, pouco discutida no debate em tela — à exceção de Sztutman (2012:320) — talvez por não remeter a um modelo patrimonialista; uma "figura conspícua" cuja "invenção quase equivale à criação da própria vida" e cuja tradução 
elaborada pelos Yudjá também é "dono". Como aponta Lima, o iwa condiciona a vida social em seu desenrolar no dia a dia, e é essa agência que torna pensável tanto a existência humana e o universo quanto "os acontecimentos mais mundanos". Trata-se daquele que, por exemplo, é o dono de um cauim, ou aquele que vai na frente, o primeiro, o que inicia uma atividade e declara o fim de sua realização (Lima 2005:95-96). Tal noção é trabalhada pela autora de maneira a traduzir aspectos fundamentais da condição humana, ao mesmo tempo em que propõe uma problematização da noção de dono, naturalmente desviada pelas "conotações que o termo tem em nossa própria vida" (Lima 2005:95). O iwa (também traduzido por dono pelos Yudjá) seria, antes de dono, um articulador de um coletivo para determinada atividade.

Conforme uma nota sobre a questão de "dono", Viveiros de Castro também observa:

Venho usando a tradução, feita pelos próprios Yawalapíti, da palavra wököti por "dono". A tradução é problemática, pois o termo indígena é usado em contextos que não são cobertos pelos conceitos ocidentais subjacentes ao uso mais comum de "dono" no sentido de proprietário (2002d:82).

Estes e outros autores lembram que a ideia é tão polissêmica quanto são as línguas faladas por esses povos: "patrono", "mestre", "representante" (Viveiros de Castro 2002d:82), e não poderíamos definir qual se sobrepõe a qual. Na língua guajá, a categoria que sempre aparecerá associada aos "animais de criação", nimá, será jara (ou jará, a depender da sentença), um conhecido termo tupi-guarani cuja glosa usual é "dono". Etnograficamente, jara aparecerá neste artigo tanto como "dono", à guisa de comparação, quanto como "criador" (como aquele que possibilita a vida), "aquele que anda junto", "cuidadores" e mesmo "duplos" (como veremos), e o rikú, a relação entre jara e nimá (usualmente, criatura), seria um método para produzir a vida coletiva, parafraseando Lima (2005:96).

Cabem, portanto, algumas observações de como os Awá concebem a vida coletiva.

\section{A criação em questão}

O ano era 2007. Em uma manhã úmida de inverno, eu acompanhava a família de Uirahó em mais uma caçada. Após sairmos da aldeia, atravessamos uma roça de mandioca, seguida de uma capoeira velha separando a floresta ( $h a k a^{\prime} a$ ) do espaço da aldeia (haripá). Antes de adentrarmos a floresta, avistei 
um grupo de borboletas brancas levantando voo. Devido à beleza da cena - e ao compulsivo interesse por tudo demonstrado por etnógrafos em campo indaguei aos meus companheiros: "como vocês chamam borboletas como aquelas?". Ele me respondeu que se tratava de borboletas brancas, pỹñ̃xũn, e emendou: kamytxa'á pỹnỹ, "são as borboletas do jabuti". Um pouco confuso perguntei se era o nome da "espécie" de borboleta, e ele me disse que não, que as borboletas eram "kamytxa'á nimá", em uma tradução literal, "animais de criação dos jabutis". A partir de então me relataram um processo muito característico da etologia awá-guajá, em que animais possuem relações do tipo rikú (de criação); alguns serão nimá (crias) ou jara (criadores) de outros, domesticando-se através de uma verdadeira teoria da relacionalidade generalizada. Desta forma, muitos seres se enxergam como jara de outros, e como tal são vistos pelas criaturas que estão juntas aos seus nimá.

Outros exemplos? Formigas tucandeiras são animais de criação de macacos guaribas; os porcos do mato criam algumas espécies de cobra; o poraquê (peixe elétrico) é cria de diversas espécies de peixes e, por sua vez, é um animal de criação para um jacaré (jakaré nimá); assim como toda espécie de mel, dentre as dezenas existentes, pertence a algum ser que é seu jara. De uma maneira geral, muitos animais caçados pelos humanos são animais de criação de outros animais. Em todos esses casos encontramos a mesma relação, jara (criador) $\rightarrow$ rikú (a relação) $\rightarrow$ nimá (cria), sendo rikú o vetor destes polos. Tal forma de relacionar mostra-se bastante normativa ao mesmo tempo em que aberta - parafraseando Descola (2006:138) - e por isso não devemos pensar que os Awá mantêm um inventário de todas as relações possíveis, entre todos os seres que vivem em seu mundo; não faz sentido montarmos um vasto quadro, com inúmeras dessas relações e possibilidades para a coerência total do universo.

Nos chuvosos meses de janeiro a março, os mosquitos pium (p $\left.\tilde{\imath}^{\prime} \tilde{u}\right)$ atacam com intensidade algumas aldeias, formando verdadeiras nuvens. A concomitância do aparecimento dos piuns com a época do pequi (mykja'á) é ilustrada por uma relação de continuidade sociocosmológica entre insetos e frutos. Ambos aparecem na mesma época e o pequi é pensado como pĩ' nimá, "seres de criação dos piuns", e os piuns, por sua vez, seriam mykja'á jará, os "donos do pequi". O agradável sabor do pequi sempre será desfrutado ao lado das inconvenientes picadas dos piuns; foram "misturados" (pãmẽ) e sempre aparecerão "juntos" (pyry). O maior empecilho para que tal relação continue em curso é o desmatamento que hoje assola o oeste maranhense.

Os Awá lembram que as chuvas são enviadas por um grupo de karawara ("humanos celestes") que controlam as águas e as mandam periodicamente para a floresta, pois, embora vivam historicamente de caça e coleta, a 
floresta é como um lugar cultivado (como sabemos que ocorre em outras cosmologias amazônicas, como os Achuar e os Waiãpi). Os karawara não enviam chuva para as áreas desmatadas, porque onde não existem árvores não existem frutas, e não haverá animais para delas se alimentar. Por serem também caçadores (watama'á), estes seres cultivam as florestas para que os animais existam e eles mesmos possam caçá-los na terra. O desmatamento, que como sempre traz consequências cosmológicas gravíssimas para os povos ameríndios, cataclísmicas, pode estraçalhar relações como esta, uma vez que existirá um mundo com piuns e sem pequizeiros; com criadores (ou donos) e sem criaturas. Mas este é um tema que não terei como aprofundar aqui.

Por vezes, jara serão os animais que consomem com mais intensidade determinados frutos. Por isso as pacas são jara do frutinho da árvore maria-preta (chamados wãwã'á). Não que animais como cotias, veados, antas, porcos, dentre outros, não se alimentem desses frutos, mas são as pacas as que os consomem com mais intensidade. Eles são a "comida da paca" (kararuhu nimi'úa), ou simplesmente estão junto às pacas, por isso elas são jara (criadoras). O mesmo acontece com várias outras espécies vegetais, algumas recebendo na classificação o nome do animal dono, com espécies como "mandioca de cotias" (akuxí tỹrỹmỹ), "pequis de tucanos" e "comida de guariba" (wariwá), dentre tantos outras. Da mesma forma, os cipós (ipoja'á) em geral são tidos como "criados" pelos macacos guaribas, e chamados de wari nimá, "seres de criação dos guaribas".

\section{Seres objetos}

A primeira vez em que escutei os Awá falarem sobre essa capacidade "criativa" foi justamente quando conversávamos sobre objetos. Amỹpirahã, que vive na aldeia Juriti, havia pedido uma faca de presente da próxima vez que eu voltasse à aldeia. "Uma faca grande!", ela enfatizou. Ao questioná-la sobre o porquê de ela querer uma "faca grande", respondeu-me: a'e rikú tá, que ela me traduziu na época como "para eu criar!". Os objetos em si, embora passem frequentemente de mão em mão, sempre terão um dono-criador, mesmo que em poucos dias ganhem um novo dono, e a relação entre diversos objetos e quem os "cria" é descrita como uma relação de "criação" (rikú). Por isso falarei brevemente sobre as flechas de um caçador, que constituem um bom exemplo (ver Garcia 2010).

Desde o contato, quando tiveram acesso às espingardas, os homens jovens caçam com arma de fogo (maká, é como chamam as espingardas). Mesmo assim, todos, jovens ou velhos, possuem o seu estoque de flechas 
e tabocas. Assim como ocorre com os seres humanos durante a caçada, as flechas e as tabocas também devem entrar em um estado de "raiva" (-imahy) para que funcionem de maneira adequada. Para que uma flecha desenvolva "raiva", é necessário que os homens lhe forneçam dois elementos cruciais: "dor" (hahy) e "sangue" (hawy), cuja melhor tradução seria "sangue-veneno". Por isso, após confeccionada, uma flecha ainda não está pronta para o uso, pois requer um longo processo de alimentação e envenenamento para que se fortaleça.

Uma flecha se alimenta fundamentalmente do sangue de suas presas. Quando um animal é morto, os homens esfregam na carne com sangue as pontas de diversas flechas para que assim sua fome seja aplacada. O sangue dos animais é o alimento para o objeto (hanimi'úa - "minha comida"), ao mesmo tempo em que é o "veneno" (hawy) que elas lançarão nas presas. É comum que os homens, enquanto estão limpando caças, levem junto algumas flechas para esfregar no corpo do animal após aberto, antes de destripá-lo e lavá-lo. Trata-se do único uso que fazem do sangue de animais, extremamente venenoso: "para as flechas, o sangue é como um remédio (pohã), enquanto para os Awá, ele é um veneno", me disse certa vez o velho Takya.

Após alimentadas, flechas e tabocas são postas a secar em um jirau sobre o fogo para que fiquem "duras" com a fumaça e para que recebam dor. Se o sangue injeta veneno na flecha, a fumaça do fogo de cozinha (tatá txin) injeta "dor". Tal defumação faz com que a flecha fique com uma tonalidade marrom, bem escura (como pó de café), tendendo para o preto, e quando ela alcança essa cor, é sinal de que está pronta para o uso, capaz de despejar veneno e dor nos animais.

Os Guajá também defendem que os muitos agenciamentos entre um caçador e suas flechas são da ordem de uma relação rikú, e parte da destreza do caçador está na ligação que ele estabelece com o seu feixe de flechas. Em outras palavras, os homens fabricam e criam suas flechas. "Criar as flechas" implica basicamente confeccioná-las, alimentá-las e repará-las sempre que necessário. Fabricá-las é apenas um primeiro passo para possuí-las, e ninguém possui uma flecha só porque a fabricou; possuí-las é obrigatoriamente "criá-las" (rikú). Muito embora tais armas de caça e guerra sejam feitas (como objetos) pelos humanos, elas têm uma autonomia a ponto de quem as cria manter uma relação homóloga àquela que estabelecem com outros seres em seu mundo. Somente tal domesticação (rikú) pode proporcionar uma vida útil (sem acidentes e tragédias) para as flechas, os cartuchos e as espingardas, e parte da destreza do caçador está na qualidade desta relação. ${ }^{17}$ 


\section{Ogros}

Diferentemente, por exemplo, dos Ka'apor ou dos Araweté, as figuras do koropí (Viveiros de Castro 1986:244) ou curupir (Huxley 1963:205) estão ausentes do mundo awá. São os ajỹ, pequenos ogros (por vezes espectros) canibais que vivem na floresta que desempenham o papel de seres controladores de alguns animais de caça, capazes, inclusive, de perseguir um caçador lançando-lhe ha'aera (uma espécie de "raiva"), e deixando-o panemuhum ("panema", sem sorte), como discuti em outro artigo (Garcia 2012b). "Seres pequenos, com a estatura de crianças, e muito feios!", esta é uma das formas de definir os ajy, que habitam antigos acampamentos, ocos de árvores, buracos e áreas escuras da floresta. Além de provocarem doenças e morte, os ajỹ são seres com os quais os Awá constantemente estão sujeitos a se encontrar, principalmente porque alguns dos animais mais caçados pelos humanos são tidos como animais de criação dos ajỹ. São eles: o veado mateiro (araphá), o veado foboca (arapha'í), a cotia (akutxí), a paca (kararuhú), e o quati (kwatxí).

Certa vez foram encurraladas uma paca e uma cotia que, desesperadas, se esconderam dentro de um tronco de árvore caído, em volta do qual permanecemos na esperança de desentocá-las. Estávamos em um grupo com cerca de dez pessoas, todos traçando estratégias para entupir os caminhos internos do tronco a fim de evitar a dispersão dos animais encurralados; tentando encontrar o melhor buraco para lançar fumaça na tentativa de asfixiar as presas; inserindo facões por orifícios para feri-las; e mesmo enfiando os braços — sob o risco de levarmos uma mordida violenta - na tentativa de agarrar o pescoço e dar cabo dos bichos. Passaram-se pelos menos duas horas sem conseguirmos capturá-los quando, por um descuido da paca, Takya conseguiu atingi-la com seu facão (enfiado dentro do tronco), matando-a. Logo depois a cotia foi morta dentro do tronco com investidas de porretes e facas dos caçadores, que esmigalharam o seu crânio matando-a com sucesso. Quando puxaram a cotia morta para fora do tronco, percebemos se tratar de uma outra paca (um pouco menor do que a primeira), mas não uma cotia, como havíamos cogitado de forma rápida e enganosa. Quando questionei alguns sobre o fato de que havíamos nos enganado - pois pensávamos se tratar de uma paca e uma cotia, e não duas pacas - me disseram que a cotia sempre esteve lá, mas foi "transformada" em paca (ipiriwá "mudar a pele") para que tivesse mais chances de sobreviver, mais força para cavar um buraco no tronco e se desencurralar.

Os ajy, que são seus jara, aqueles que os criam, teriam promovido tal transformação. A partir desse momento rememoraram episódios semelhantes envolvendo pacas, cotias e buracos; quase sempre nesses episódios a cotia era transformada pelos ajỹ em uma paca, com vistas a se salvar dos huma- 
nos caçadores. Tais transmutações nunca são espontâneas, mas propiciadas pelos ajy, seus controladores. Com o ajỹ mit, "sopro dos ajy" , outros animais de criação dos ajỹ (ajỹ nimá) também são transmutados, sempre de forma simétrica entre dois seres equivalentes segundo uma certa taxonomia dos ajỹ. Desta forma, um quati (kwatxí) pode se transmutar em um gambá (ajỹ), e vice-versa; um veado-mateiro (arapha) ou veado foboca (araphaí) pode ter a tonalidade ocre de sua pele modificada para cinza, transformando-se em veado cinza (araphá pihúna). Como o alcance do poder dos ajỹ é limitado e não se estende a todos os animais - porcos, caititus, antas, todos os macacos (com exceção do macaco-da-noite), dentre outros - estão isentos dessas mudanças (ver Garcia 2010:245-248).

Em paralelo, veados, pacas e cotias, mesmo sendo animais de criação dos ajỹ, mantêm entre si relações de consubstancialidade do tipo harapihiara (parentes próximos). De acordo com os Awá, as relações entre eles são do tipo rikú: uma paca é, para ela mesma, dona (jara) de uma cotia, e animal de criação (nimá) para um veado. Apesar de estarem, por assim dizer, na "área de influência" dos espectros canibais ajỹ, esses animais são concebidos a partir de uma linha de continuidade que coloca uns como criadores de outros. Isto não é meramente um discurso abstrato sobre o mundo, mas implica diretamente a vida das pessoas, sobretudo no que concerne à caça. O rikú opera como um princípio sociológico que mobiliza relações entre esses seres sem necessariamente passar pela perspectiva humana. Os Awá apenas concebem como os animais concebem tais relações. Se determinadas borboletas são seres de criação dos jabutis, ou se os cuxiús-pretos o são de macacos-prego, é algo atuante entre tais seres, escapando ao controle humano. Kwá kĩjé, dizem os Awá, "É assim mesmo!".

\section{Os mais diversos xerimbabos}

A forma rikú também ocorrerá entre parentes próximos como uma maneira de produzir consubstanciação conjugal e proximidade genealógica (Viveiros de Castro 2002a:157), bem como expressará formas de adoção (Fausto 2001:413-418). É isto que, por exemplo, Cormier defende para a relação existente entre as mulheres e seus xerimbabos. Em seu livro Kinship with monkeys, impressionada com a obsessão das mulheres em criar dezenas de bichos nas aldeias - algumas possuem cinco ou mais macacos - afirma que, sobretudo com o guariba existe uma relação direta de perfilhação que transforma aquele pequeno e cativo animal em um filho para a mulher, que inclusive o amamenta. A autora enfatiza a criação desses animais como um 
dos principais atributos da feminilidade e da maternidade (Cormier 2003). Observo, porém, que a ideia de nimá (crias) não se encerra nas relações humanos-animais do tipo humanos-animais de criação, pois nimá será qualquer ser que estiver sob o domínio de um jara (criador).

Se a relação entre os animais de criação e seus donos que os criam aparece como perfilhação, como diversos autores discutem (ver Cormier 2003 para o caso awá; Erikson 1897, 2012; Fausto 2008), ocorre ainda de essa posição jara ser concebida como própria da mãe (e por vezes do pai) de crianças. Então, se uma mulher sabe ser dona de um xerimbabo, ela o é, antes, porque ela sabe ser dona de seus filhos. Pude ver certa vez o velho Pirama'a pegando o seu filho ainda bebê, que chorava muito, enquanto ele dizia para o filho mais velho: ajáhó ja pe!, "leve-o para a dona dele", forma sinônima de "leve-o para sua mãe". Jara aqui estaria muito mais próximo do iwa Yudjá, como aquele que possibilita a vida de determinados seres (filhos ou xerimbabos), do que de um "proprietário", já que uma das principais tarefas de qualquer jara é garantir o crescimento de alguém (nixa'á " crescimento dele"). ${ }^{18}$ Para melhor ilustrar a amplitude desta ideia, forneço mais alguns exemplos.

Uma aldeia awá-guajá pode ser um local bem desconfortável! Quem afirma isso não sou eu, são eles próprios. Acostumados ao frescor e à liberdade da floresta, onde permaneceram vivendo até o contato recente, a aldeia, que veio como parte do "kit pacificação" (refiro-me à agricultura, aos utensílios e à espingarda), ainda é algo novo para as pessoas. Um local mãnãhỹ (feio), enquanto a floresta seria pãrãhỹ (bonito). Parafraseando Viveiros de Castro ao escrever sobre os Araweté (1986:70), ${ }^{19}$ as aldeias dos Awá estão junto a Postos Indígenas, e não o contrário; a aldeia em si é muitas vezes chamada por eles de "Funai". Os tapirís (tapã'í) cederam lugar às casas de taipa, e a concentração de pessoas em aldeias trouxe, além das galinhas e dos cachorros, muitas baratas.

O amontoado de coisas e comida que os Awá estocam em seus telhados de palha e brechas de parede é tamanho que, nas noites de inverno principalmente, uma miríade de baratas aparece zanzando em boa parte dos espaços das casas, do chão ao teto. Nas noites úmidas de inverno sobem por nossas pernas, circulando por todo o corpo, por dentro e por fora da roupa, da cabeça aos pés. A quantidade de baratas é tão grande que eu tive que me acostumar quanto aos movimentos delas por meus braços e pernas. Quando espantamos uma do braço, duas já estão no tornozelo.

Certa vez, conversando sobre o desconforto que as baratas traziam à aldeia Juriti, Uirohó, um homem, me disse que elas eram de responsabilidade da Sucam (extinto órgão da Fundação Nacional de Saúde). Disse mais, que as baratas eram sucam nimá, isto é, "animais de criação da Sucam" (criaturas cuja vida e controle da vida eram propiciados pela Sucam). 
Em linhas gerais, a Sucam é jara (dono, criador) das baratas. Segundo Uirohó, a Funai foi a responsável por trazer as baratas até a aldeia, porém, por não ser uma jara das baratas, a Funai teve que chamar quem realmente as sabe criar, a antiga Sucam - ela, sim, sabia controlar a praga. Cada vez que um funcionário da Sucam vai até a aldeia, ele não está lá para exterminar as baratas, mas sim para controlá-las, elas são as suas "criaturas".

Quando abatem animais grandes, como porcos, veados e principalmente antas, os Awá, maldizendo o animal, queimam com um ramo seco de palhas os pelos do bicho a fim de tirar todos os carrapatos. Reclamam da anta, por exemplo, por "gostar de criar tantos carrapatos". Dizem: tapira jatikôa rikú (anta + carrapatos + criar). As mordidas de carrapato que qualquer um de nós ganha nas caminhadas pela mata são associadas a um animal específico: "Esses são os carrapatos de um veado que passou por aqui", ou "eu fui mordido pelo carrapato daquele porco, ou daquela anta". Não que neste caso as antas, os porcos e os veados controlem os carrapatos, mas, diferente disso, os carrapatos apenas "estão com" esses animais. Desta maneira, os Awá ressaltam que uma definição mínima para jara seria "aquele que está junto", pensada sob o signo da relação rikú que, além de "criar", ela mesma é traduzida, como já pontuei, por "estar com".

Os carrapatos são uma chateação para todos, tal como as baratas e algumas espécies de cobra. Se dependesse das pessoas das aldeias, elas manteriam tais bichos bem longe, em nada diferente do que nós mesmos pensamos e fazemos. Porém, quando os Awá dizem que os carrapatos e as baratas só vivem a partir desses jaras, de forma diversa da nossa, estão enfatizando que aquilo que nós chamamos de "praga" é para eles um descontrole de outra ordem, de uma ordem sociológica, na qual a relação entre não humanos pode ser pensada como são pensadas as relações entre pessoas, e não como um desequilíbrio ambiental.

Como mais um exemplo, em uma crise de malária na virada do ano 2000, só controlada nos idos de 2003, após estabelecida a saúde da aldeia, os Awá pediram para que a auxiliar de enfermagem que trabalhou tratando dos doentes (fazendo lâminas, diagnosticando e administrando os medicamentos) parasse de trabalhar naquela aldeia. As pessoas entendiam que a funcionária era uma espécie de "dona da malária". O velho Irakatakôa perguntou-me: Maria malaria mixa'á nenehẽ apó?, "Será que a Maria ${ }^{20}$ está criando (cultivando) a malária (aqui na aldeia)?"; A'e Maria malaria jara apó?, "Será que Maria é a dona da malária?". Por ter estado no olho do furacão de uma crise de malária e ter conseguido controlá-la, foi entendido que Maria conseguia dominar a malária. Para eles, a prova disso veio com a sua saída, pois desde então não houve mais casos da doença, controlada há mais de uma década. 


\section{Cosmologia e criação}

Além dos exemplos citados, também é jara uma complexa classe de seres celestes, chamados karawara, um grupo que envolve ex-humanos, espíritos de outros povos (como os Tenetehara) e animais. Os karawara são gente, dizem os Awá, humanos de verdade (awáte), porém uma gente que vive no céu; são relacionados a pequenos animais, insetos, plantas e alguns objetos. Seriam, por exemplo, uma gente pica-pau, gente juriti, gente tucano, papagaio, siricora, sabiá, várias borboletas, marimbondo, gente taquara, dentre outras plantas e bichos, também referidos como jara. Todos são exímios caçadores e, embora vivam no céu (iwá), mantêm um trânsito constante com a terra, para onde descem a fim de buscar, basicamente, caça, água, mel e, por vezes, fogo, produtos essenciais ao desenrolar da vida celeste, e para ajudar os humanos em curas xamânicas. Possuem uma imagem humana celestial definida: bem adornados com cocares e braceletes, habitantes de um lugar limpo e agradável, caçadores infalíveis. Uma gente celeste cujas carcaças animais seriam suas formas terrenas.

Cada um é especializado em um tipo de caça ou atividade, como, por exemplo, o karawara phu'uá jará (gente pipira-de-bico-vermelho), que é um caçador de macacos-prego; o makaró (gente pomba-galega), cujo canto de caça é bastante apreciado pelos humanos, sendo um grande caçador de porcos; o xakará jará (gente gavião-caracoleiro e "gente-gavião-de-cauda-curta"), um caçador de guaribas; o taky jará (gente tucano-de-bico-preto), que se alimenta de bacabas; o waká jará (gente caranguejo-do-rio), um caçador de veados; e o hairá jará (gente irara ou papa-mel), que desce a terra para coletar grande quantidade de mel. Quando as pessoas encontram uma colmeia seca na floresta, foi hairá jará que desceu a terra e coletou o mel, não deixando nada para eles. Cada karawara é "comedor" (u'uara) de determinado tipo de alimento: caçam e comem especificamente um único tipo de caça. Eles têm uma dieta exclusiva, como, por exemplo, as entidades

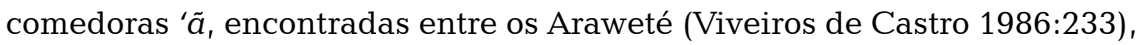
que também comem alimentos específicos. Algumas plantas, como a bacaba e o inajá, também possuem uma forma humana celeste, karawara. Por exemplo, Inajá jará (gente inajá) é um grande caçador de guaribas, e Kiripi Xa'á (gente palmeira ubim) é um caçador de saguis (chamados atamari'í).

Encontramos com os karawara uma correlação entre a ideia de jara e a de "humanidade celeste", por assim dizer. Os karawara são referidos enquanto jara. Por exemplo, inajá jará, cuja tradução remeteria a "dono dos inajás", é pensado não em função do que supostamente "criaria" (inajás), mas sim quanto ao que efetivamente caça: guaribas, no caso. Inajá jará, 
diferentemente de um "dono dos inajás", aparece como um tipo de gente que habita o céu (uma multiplicidade: homens, mulheres, crianças), a gente inajá jará, cujo alimento são guaribas; e assim será com todos os outros karawara. A ideia de jará, nessas circunstâncias, se aproximaria de outras ameríndias, tal como a noção marubo de vaká, algo como duplos "cuidadores" ou "protetores" (Cesarino 2010:152). Aqui, os correspondentes terrenos (plantas e animais, por exemplo) não seriam seres de criação de donos celestes, mas correspondentes terrenos dessas potências.

A própria cosmografia awá ajudaria a pensar a domesticação como um acontecimento que transcende barreiras socioespaciais. Além da terra (wy), local onde vivem os humanos, o mundo é dividido em diferentes patamares. Acima da terra há diversos patamares (iwá), cada um habitado por diferentes grupos de seres. Como vimos, muitos jara estão no céu, e muitos desses jara celestes têm uma predileção especial em criar determinados tipos de seres. Portanto, a esposa do Mikya'á Jará (gente poraquê) gosta de macacos-prego, criando-os aos montes; já o Kaá Jará, (gente marimbondo) cria kamarás (outros indígenas, Guajajara e Ka'apor, por exemplo). No céu os kamará vivem soltos, "como as galinhas da aldeia" ao redor da casa de Kaá Jará.

Há um patamar subterrâneo ao qual os Awá não têm acesso. Este local não é muito diferente da terra — com suas árvores e rios — sendo que a diferença fundamental entre o patamar dos humanos e o patamar subterrâneo está no fato de lá as pessoas criarem animais domésticos em grandes quantidades, tal como os karaí (brancos) criam gado. Uma mulher pode ter centenas ou milhares de nimá. As aldeias seriam como "fazendas" (dizem os Guajá) que, ao invés de gado e cavalos, teriam queixadas, caititus, veados, macacos e diversos outros animais de criação. Esses humanos subterrâneos voltam da caçada carregando diversos filhotes e, ao invés de soltarem os filhotes no mato após alguns anos (tal como fazem os humanos), eles os deixam presos a se reproduzir. Nem os soltam como os Awá, nem os comem como os karaí (brancos). É um local onde prevalece o exagero da domesticação de animais, levada às últimas consequências.

Esta ideia de "fazendas" de animais selvagens aparecerá transformada no que diz respeito a outros povos amazônicos, referindo-se ao universo dos "mestres de animais", como no caso das haciendas amazônicas, descritas por Kohn (2007:116), onde os animais da floresta vivem em currais, controlados e alimentados por seus mestres, utilizando a floresta para o seu usufruto; os cercados onde vivem os porcos do Senhor dos porcos na cosmologia araweté (Viveiros de Castro 1986:234); ou os currais dos Karitiana, que deram origem aos animais da floresta, descritos por Vander Velden (2010:147-148). Como contraexemplo das haciendas e currais, o caso awá-guajá evidencia que os 
humanos que aprisionam os animais em tais locais não seriam os mestres que os controlam e soltam na floresta, ${ }^{21}$ mas sim a caricatura de uma humanidade que cria animais de forma desmedida e descontrolada.

\section{Andar junto}

Como vimos até aqui, relações entre diversos seres gravitam semanticamente em torno da ideia de rikú. No quadro abaixo retomo algumas possibilidades reveladas por tal ideia.

\begin{tabular}{|c|c|c|}
\hline Possibilidades & Exemplos & $\begin{array}{l}\text { Relações rikú/criação } \\
\text { (jara/criador } \rightarrow \text { nimá/cria) }\end{array}$ \\
\hline a) & pais e filhos & awá (humanos) $\rightarrow$ awá (humanos) \\
\hline b) & maridos e esposas & awá (humanos) $\rightarrow$ awá (humanos) \\
\hline c) & $\begin{array}{l}\text { mulheres e animais de } \\
\text { criação }\end{array}$ & awá (humanos) $\rightarrow$ animais \\
\hline d) & $\begin{array}{l}\text { pessoas na terra (jara) } \\
\text { seus duplos celestes (nimá) }\end{array}$ & awá (humanos) $\rightarrow$ não humanos \\
\hline e) & Funasa e baratas & karaí (não indígenas) $\rightarrow$ pragas \\
\hline f) & $\begin{array}{l}\text { veados e pacas; todas as } \\
\text { relações entre jara e nimá } \\
\text { animais }\end{array}$ & animais $\rightarrow$ animais \\
\hline g) & animais e abelhas/mel & animais $\rightarrow$ animais/alimentos \\
\hline h) & ajỹ e macaco-da-noite & ogros não humanos $\rightarrow$ animais \\
\hline i) & $\begin{array}{l}\text { um karawara chamado kaa } \\
\text { jará tem uma espécie de } \\
\text { marimbondo como nimá, } \\
\text { além de ser um caçador de } \\
\text { macacos-prego }\end{array}$ & $\begin{array}{l}\text { karawara (não humanos) } \rightarrow \text { xerimbabos } \\
\text { terrenos e caças terrenas }\end{array}$ \\
\hline
\end{tabular}


A partir destes elementos, observamos que a noção de rikú produz relações que atravessam diferentes formas de subjetividade. Dentre elas está a conjugalidade. Muito embora os Awá não mencionem nenhum verbo para casar, em todas as indagações sobre o casamento me ofereceram o rikú como a ideia de relação entre marido e esposa. Portanto, se rikú não é apenas casar, o casamento só será entendido a partir da compreensão desta ideia.

Sabemos que em diversas sociocosmologias sul-americanas (por exemplo, entre os Achuar, os Waiãpi, e até mesmo os históricos Tupinambá) o casamento é descrito como um processo de, nas palavras de Anne Christine Taylor (2001:49), "amansamento" da esposa, muitas vezes desposada ainda bem jovem. No caso dos Achuar, por exemplo, o casamento é modelado por uma relação de "captura violenta", já que na prática muitas esposas eram fruto de expedições guerreiras entre os diferentes grupos, havendo uma conexão entre conjugalidade, amansamento, sedução e caça (Taylor 2001:49). Para os Waiãpi, lembra Gallois (1988), o "apresamento" de mulheres é algo tributário de um estado indômito das esposas e das mulheres em geral, cuja captura e domesticação são necessárias à transformação da jovem. O mesmo acontecia com os Parakanã, que davam preferência às jovens "pois as mais velhas eram difíceis de "pacificar e, por vezes, resistiam à captura" (Fausto 2001:300). Segundo os Guajá, quando mencionam os grupos que vivem sem contato com a Funai (os isolados, chamados mihúa, "a gente braba"), uma das principais preocupações dos homens é com as possíveis esposas que poderão adquirir a partir do contato.

Há, portanto, a necessidade de transformar uma jovem menina em esposa. São diversos os motivos elencados (de ordem econômica, ecológica e sexual) para a preferência em se casar com um parente tão próximo e tão jovem, e todos alegam a necessidade de "criar" a esposa, a fim de que ela não entre em um estado de raiva incontrolável, destino a que toda mulher está sujeita caso, por algum motivo, não se case. ${ }^{22}$ Uma mulher não pode crescer sem estar casada, e não é recomendável que ela demore para arranjar um marido, pois cresceria muito "zangada". ${ }^{23}$ O que acontece com a jovem esposa awá é algo parecido com o que Fausto (2001:432) demonstra quanto às mulheres raptadas pelos Parakanã: uma relação direta entre "raiva", "comida" e "casamento", na qual o alimento aplaca a raiva e possibilita o matrimônio.

Os Awá têm diversas frases que ilustram o processo conjugal, como, por exemplo: apy ta hamiriko nime, "vou pegá-la como esposa"; ou então: amẽmakwá ta hãrẽhẽ, "eu vou amansá-la", uma frase utilizada por casais de qualquer idade, quando ainda estão se conhecendo e se convencendo de seus planos futuros; e ainda a mais utilizada maj maná, "vou mandar (para 
ele) criar", como já observei. O jovem Xiparenxa'á, que estava gostando muito (maparỹ) da jovem Majrá, que vive em outra aldeia, explicou-me que a ideia de amẽmakwá ("amansar"/ "acostumar") ilustraria o "namoro", algo análogo ao ato de uma mulher trazer um filhote de cotia do mato para criar. De acordo com Xiparenxa'á, "a cotia chega brava e tem que ficar calma". A fase de proximidade e conquista, maparỹ ("gostar") ou maparahỹ ("tomar gosto"), é traduzida pela ideia de amansamento/acostumar-se (amẽmakwá), processo que pode durar anos, e nem sempre quem "amansa" e "cria" (rikú) será aquele que terminará "junto" (pyry) à mulher. Vejamos.

O velho Xipohá, de 54 anos, um dos fundadores da aldeia Awá (TI Caru), é um segundo pai para o jovem Inamupihi'ũa, de 17 anos. Marido de sua mãe, seria ele um tunewena $(\mathrm{MH})^{24}$ para o rapaz, como dizem as pessoas desta aldeia. Xipohá há alguns anos havia "pego" (harimiriko py, "pegar uma esposa") a jovem Tikwi'a, hoje com 16 anos, para criar. Ela passava parte do tempo na casa de Xipohá, acompanhava as outras duas esposas em suas atividades, sendo "criada" por elas também, tal qual uma filha. Como Inamupihi'ũa também frequentava essa casa, aos poucos ele e a jovem Tikwi'a, que são da mesma geração, passaram a gostar um do outro (maparahỹ, "tomar gosto") e, antes que Xipohá pudesse fazer qualquer coisa, os dois jovens começaram a namorar. A jovem largou o homem que a estava criando como esposa para se casar com o rapaz que este também chamava de "filho" (haxa'á). É como se Tikwi'a tivesse sido "pega" (-py) ainda na infância justamente para ser "criada" (rikú) — como se a conjugalidade fizesse as vezes de uma segunda paternidade - e quando decidiu escolher um marido de fato, optou por ficar com alguém que, em uma imagem mais ortodoxa, seria o "filho do marido", como veremos agora, criando-o também.

O que está sendo enfatizado aqui, elencado nesses tantos exemplos, é o fato de que quem contará como jara será quem "está junto" (riku pyry) de quem, mas não necessariamente controlando-o como um ser de criação. Quem está junto de quem é algo que a sociologia awá toma como um princípio modelar, e pode ser encontrado através de outras tantas ideias muito utilizadas, que aparecem com frequência na fala, como, por exemplo: harimirikô imakwá ta hapyry, "trazer a esposa para esperar perto de mim", para justificar a união intergeracional; e durante o casamento é comum um homem ou uma mulher dizer que está casado(a) através da interjeição amãja, "eu criei", utilizada por homens ou mulheres para se referirem ao cônjuge, como mencionado no início do artigo; e ainda watá pyry ("andar junto"), ideia que talvez resuma a vida nas aldeias awá. Ao mesmo tempo, o que parece estar implícito nesses encontros conjugais é a assimetria geracional como uma variante importante no processo, tal como o episódio inicial deste 
artigo tentou revelar. Tudo se passa como se o rikú, a relação por excelência, prescrevesse tal desequilíbrio, tal assimetria.

Essa máquina de produção de cônjuges é, guardadas as devidas diferenças, literalmente operada por homens e mulheres. ${ }^{25}$ Mulheres trocam maridos velhos por homens jovens, principalmente as mulheres jovens, como vimos no caso acima. Além disso, as mais velhas justificam o casamento com homens de gerações inferiores argumentando que o marido jovem "caça mais" para elas. O rikú, como um modulador da aliança, é aplicável para ambos os sexos: maridos criam esposas e esposas criam maridos. Muitas mulheres viúvas que casaram novamente dizem "criar" (rikú) seus jovens maridos, pois o perigo, neste caso, é o rapaz entrar em um profundo estado de melancolia por não possuir uma esposa, capaz de comprometer inclusive a sua produtividade na caça, talvez o pior mal que pode se abater sobre um homem. Tal união (com mulheres de gerações ascendentes) é característica não só dos regimes avunculares, como sabemos desde os Tupinambá, mas também de outros casos amazônicos. Em sua etnografia sobre os Asuriní do Xingu (que também se pensam awate, "gente de verdade"), Müller mostra como as mulheres participam da "formação da personalidade masculina" através do casamento intergeracional:

Aquele que eu criei (jeremymĩga) tem este sentido, como termo de referência usado pela esposa mais velha para o marido jovem. É frequente ouvir as Asuriní comentarem que uma mulher mais velha (uma parente próxima) deu (kae) a elas o marido, a quem ajudou a formar. Ela o ensina, contando mitos, histórias do passado [...] Exige dele o cumprimento das tarefas de roça e coleta para as quais ela está dando, nesta fase de sua vida, a capacidade máxima do desempenho físico (Müller 1993:123).

No caso awá-guajá, as mulheres declaram literalmente jahá amixa'á ta hamenime, "eu vou criá-lo para ser meu marido", em que a ideia de -ixa'á denota o desenvolvimento físico de um ser. As mulheres podem transmitir conhecimentos sobre como rastrear um animal de caça, como me contou certa vez Uirahó, ao relatar que sua esposa mais velha ensinou-lhe a "andar" (watá) no mato, isto é, caçar. Em suma, de um lado, temos mulheres zangadas e, de outro, homens melancólicos, ambos estados indesejados, sendo o enlace matrimonial uma das maneiras mais eficientes para aplacar tais estados.

A própria tradução literal para "esposa", harimiriko, é "aquela que está comigo" ou "aquela que eu crio", se observarmos que o "riko" presente em harimiriko ("minha esposa") é a forma arcaica do verbo rikú, como nota Magalhães (2007). 


\section{A ficção do dono (conclusão)}

A ideia de um mundo repleto de entidades distintas entre si, relacionadas como jara e nimá (cria), relações que circunscrevem a humanidade, e na qual a tradução de jara nem sempre será "dono" mas sim "criador", "quem anda junto", "duplos", "cuidadores", como vimos aqui, é fundamental para o entendimento do sistema de aliança em questão. Rikú é um conceito-chave tanto para o parentesco quanto para a socialidade mais ampla, envolvendo a própria chefia awá-guajá sob a ideia de tamỹ, "um propiciador de ações", que "anda junto", tal qual um chefe clastriano (ver Sztutman 2012:317-322).

Por isso, iniciei o texto alertando que, de alguma forma, a noção de "dono" (com sua "maestria", "familiarização" etc.) — tal como a utilizo — funciona como uma imagem-guia, "uma ficção antropológica" (Viveiros de Castro 2002e:123; Strathern 2006:36) que mobilizo para recolocar o problema do parentesco entre os Awá. Tal "ficção" incide no fato de tomarmos o rikú como um conceito que nos permite compreender não somente as relações awá de parentesco, mas também aquelas que chamamos ecológicas, tendo em vista que animais e plantas estão imbricados nesse universo relacional.

Não estou advogando que fujamos da noção de dono, mas cuidando para oferecer um rendimento ao conceito a partir de ideias propriamente guajá. Menos do que demonstrar a inaplicabilidade deste ou daquele conceito específico, minha tentativa aqui foi deslocar a metáfora do dono de maneira a colocá-la em uma posição imanente às ideias etnográficas. Uma característica do rikú awá-guajá, em comparação às relações amazônicas análogas, está no fato de tal ideia se associar tanto a uma "teoria da relacionalidade generalizada" (Viveiros de Castro 2002c:422) quanto a uma ontologia da familiarização, que prescreve o mundo permeado por relações do tipo donos (Fausto 2008).

Essa relação ocorre em diferentes esferas da vida, sem necessariamente reduzir uma à outra ou, "num mundo em que as relações sociais são objetos das transformações das pessoas entre si, vemos que aqui as relações sociais só podem se transformar em (outras) relações sociais" (Strathern 2006:262, grifo da autora). Trata-se, portanto, de um conceito capaz de articular ordens muito diferentes entre si: sexual/matrimonial/alimentar; animais e humanos; seres animados e inanimados, dentre outras. É um mecanismo replicador e de infinita reprodução, que faz com que seres se aproximem de outros seres, atravessando as fronteiras que concebemos existir entre espécies. Certamente, a possibilidade sugerida aqui de encontrarmos relações em toda parte constitui um fato desconcertante (Strathern 2014 [1995]:269), porém, de muitas maneiras, a intenção desta reflexão foi demonstrar como 
elas estão de fato por toda parte no mundo awá-guajá, ainda que em níveis de complexidade e escalas desiguais. ${ }^{26}$

Tal conceito parece se aproximar de uma ideia awá-guajá sobre a própria ideia de relação, na qual o casamento seria uma das formas em particular. Parafraseando Corsín Jimenez e Willerslev (2007:537), minha etnografia sugere que o rikú guajá possa ser entendido como a "reescrita do conceito euro-americano de relação" — definido aqui como a conexão entre dois seres, dois fenômenos ou duas grandezas. No caso em questão, pelo menos em um plano que envolve os humanos e um vasto grupo de seres, além de diversos objetos, "relacionar-se" é desempenhar ações que giram em torno da ideia de "criar". Não que o parentesco, apresentado aqui a partir da aliança conjugal, seja projetado para o mundo natural (tal como no modelo animista), onde todas as relações reflitam o parentesco, mas, ao contrário, sendo ele um caso particular de uma matriz relacional mais ampla. ${ }^{27}$ Trata-se de uma teoria sobre a relação, por assim dizer, em que a conjugalidade é uma das relações possíveis.

A socialidade aparece neste texto através da "reescrita etnográfica" (Corsín Jimenez \& Willerslev 2007) de ideias como relação, parentesco e termos congêneres, cuja intenção mesma está em torcer conceitualmente os termos, e não inseri-los em nosso universo conceitual. ${ }^{28}$ Daí, o esforço deste artigo não está em associar diretamente esposas e maridos a "crias", mas sim observar como de um campo se passa ao outro nesta (cosmo)lógica, estabelecendo conexões entre entidades que para o "ocidente" são pouco prováveis (Strathern 1995:15-16). Isto não significa que a relação esteja em toda parte (embora ela esteja em muitos lugares, como venho argumentando), mas quase sempre aparecerá de certa maneira para alguém, impossibilitando a existência de um "espectador absoluto" (Lima 2005:88) ${ }^{29}$ que penetre em diversos níveis de realidade em um processo de construção autossemelhante (Strathern 2014 [1995]:278).

O conceito de rikú deve ser observado não como um operador "intra-antropológico" (capaz de explicar somente o casamento), mas sim como um "operador transontológico" (que associa humanos e não humanos), tendo em vista que o humano não é mais uma essência para o parentesco (Viveiros de Castro 2007:107). Para pensar esse processo de produção de relações, o parentesco é retirado de sua zona de conforto terminológico e aparentemente pensado a partir de relações que foram denominadas como de "maestria", o que nos obriga a repensar esta última. Em outras palavras, ao menos no caso awá-guajá, maestria e conjugalidade aparecem como metáforas uma da outra, instanciações de uma relação mais ampla, a criação, ou simplesmente rikú. 
Uirá Felipe Garcia é professor da Universidade Federal de São Paulo (UNIFESP), Departamento de Ciências Sociais. E-mail: <ufgarcia@gmail.com>

\section{Notas}

* Agradeço à Fapesp pelas bolsas de doutorado e pós-doutorado, com as quais esta pesquisa foi realizada. Versões anteriores deste artigo foram apresentadas em seminários no PPGAS do Museu Nacional (UFRJ), Universidade Estadual de Campinas (Unicamp) e Universidade Federal de São Carlos (UFSCAR). Agradeço aos convites dos organizadores dos seminários Marcio Goldman e Eduardo Viveiros de Castro (Museu Nacional); Felipe Vander Velden (Unicamp); Jorge Mattar Villela e Marcos Lana (UFSCAR). Agradeço ainda ao público participante em todos os seminários que propuseram questões ao trabalho. Finalmente, agradeço a Vanessa Lea e Fabiana Maizza pelas leituras e comentários na versão final.

${ }^{1}$ Uso aqui "gostar" (no sentido de "enamorar-se de alguém", de propiciar o estabelecimento de laços conjugais) como correspondente português para a ideia expressa pelos Awá-Guajá com os termos maparỹ ("gostação") ou maparỹhỹ. Embora saiba não existir equivalentes para a ideia de "amor romântico" em um grupo como os Awá, com o casamento passando por outras afecções, optei por esta glosa a fim de contribuir com a economia textual. Voltarei a este ponto.

${ }^{2}$ Conhecida como "aldeia Awá", homônima ao antigo posto indígena perto do qual ela se formou, na Terra Indígena Caru.

${ }^{3}$ Entre os Achuar, a sobrinha cruzada não é uma "consanguínea", mas a união com ela é vista como "promíscua" (Descola 2006:249-251).

4 “Trata-se de uma união que não é nem proibida nem completamente aceita; ela representa uma possibilidade matrimonial que é parcialmente incestuosa e parcialmente legítima" (Rivière 1969:X, minha tradução).

${ }^{5}$ Para uma importante discussão sobre o tema, ver Overing (1977).

${ }^{6}$ jahá a-mixa'á ta ha-men-ime" - eu criar fut. meu-marido-caso translativo.

${ }^{7}$ Sobre as "três afinidades", ver Viveiros de Castro (2002a:128). 
${ }^{8} \mathrm{O}$ nominador "awá" é utilizado por diversos grupos Tupi-Guarani da Amazônia, como os Parakanã (Fausto 2001), Asuriní do Xingu (Müller 1993) e Ka'apor (Balée 1994), e "awá" aparece no presente contexto não como um etnônimo, como em "nós, os brasileiros", mas sim como uma categoria de pessoa humana, por exemplo, "nós, os humanos". Tal termo que designa "humanos" ou "gente" atua em oposição a outros termos, como kamará (indígenas de outras etnias), karaí (não indígenas) e mihúa (os Awá desconhecidos, amigos ou inimigos em potencial).

${ }^{9}$ Terras Indígenas Caru, Awá e Alto Turiaçu, todas no estado do Maranhão.

${ }^{10}$ Ver, por exemplo, o site da ONG inglesa Survival International: http://www. survivalinternational.org/pt/awa. Acesso em agosto de 2013.

${ }^{11}$ Tal como ocorre com outros grupos nas terras baixas da América do Sul (como os Parakanã, Trio, Cinta-Larga, Panare, além dos antigos Tupinambá), os Awá-Guajá apresentam uma terminologia de parentesco de variante dravidiana (ou de cruzamento tipo "A", de acordo com Trautmann \& Barnes 1998), marcada por equações transgeracionais e preferência avuncular na regra de casamento. O sistema de parentesco awá-guajá foi devidamente descrito por Cormier (2003), e retomado mais recentemente no meu trabalho (Garcia 2010).

${ }^{12}$ A pronúncia variará de acordo com a aldeia. Como algumas são distantes entre si, as trocas linguísticas dessas populações variaram durante sua história, resultando em pequenas diferenças lexicais.

${ }^{13}$ Foi Marcio Silva que me alertou para o fato da tradução de rikú, tal como em outras línguas tupi, ser "estar com", noção que, como veremos, também faz referência ao caso guajá.

${ }^{14}$ Muito comum às línguas tupi-guarani, os cognatos -reko e -teko foram traduzidos de formas diferentes por linguistas e antropólogos.

${ }^{15}$ A maioria das pessoas das aldeias Juriti (TI Awá) e Awá e Tiracambu (TI Caru) é constituída de melhores falantes do português do que eu de guajá.

${ }^{16}$ Mesmo Fernandes, ao se debruçar sobre a economia tupinambá, ressalta a peculiar forma de domesticação de animais empreendida naquelas aldeias - já que as fontes quinhentistas destacavam a domesticação de animais como algo muito presente entre os Tupi antigos. Desde animais de selva, como macacos, papagaios e tatus, até cachorros e galinhas trazidos por europeus, as aldeias eram espaços onde a domesticação desses animais era praticada não para fins econômicos, como sabemos, pois, conclui, "parece que os animais domésticos se tornavam tabus alimentares" (Fernandes 1963:92).

${ }^{17}$ Hoje há uma transformação dessas características para a espingarda e os cartuchos, mas não tenho espaço para explorar aqui, pretendo retomar o assunto em outro artigo. 
${ }^{18}$ Este tema tem mobilizado diversos debates na antropologia do parentesco contemporânea encarnados na discussão em torno da ideia de nurture, passando "por análises que, incorporando fenômenos da ordem da troca e partilha de alimentos, de suas ressonâncias e efeitos sobre afetos e disposições, promovem um questionamento da barreira entre nature e nurture que subjaz às concepções modernas do parentesco, assim como, inevitavelmente, à grande parte da reflexão antropológica sobre o tema" (Coelho de Souza 2004:28; ver também Battaglia 1985; Strathern 1999; Carsten [org.] 2004; para a Amazônia, ver Gow 1997; Overing 1999; Rival 1998).

19 "O que há no Ipixuna é menos um Posto Indígena junto a uma aldeia, que uma aldeia Araweté junto a um Posto" (Viveiros de Castro 1986:70).

${ }^{20}$ Nome fictício.

${ }^{21}$ A passagem entre o patamar inferior e a terra ficou inutilizada ("entupida") após a separação dos patamares no tempo mítico (Garcia 2010:69-71).

${ }^{22}$ Tal como um inverso espelhado do caso melanésio (e não apenas pela endogamia local em face da exogamia clânica), em que as "mulheres já são esposas em virtude de serem irmãs" e o casamento apenas torna visível sua transformação de um estado para outro (Strathern 2006 [1988]:337), podemos sugerir que no caso guajá uma irmã (para ficarmos nos termos melanésios) deve ser transformada em esposa por um outro homem.

${ }^{23}$ Da mesma maneira que entre os Parakanã "o marido 'cria' (-pyro) sua esposa pré-púbere dando caça para ela" (Fausto 2001:432), dar comida para a esposa (e para os sogros) é uma das principais atribuições do marido nesse período.

${ }^{24}$ A ideia de tunewena está relacionada conceitualmente ao tema da produção de crianças e à múltipla paternidade. Trata-se de termo reservado tanto aos homens que participam da copaternidade de uma criança (um "pai fraquinho", como me disse um amigo), ou simplesmente um $\mathrm{MH}$, muitas vezes sendo a mesma pessoa. Para mais detalhes, ver Cormier (2003:64-65) e Garcia (2010:165).

${ }^{25}$ É importante notar que homens prestam um longo "serviço da noiva", que pode durar anos de suas vidas, tendo que abastecer a família da esposa com carnes e outros alimentos. Há diferenças, portanto, no que homens e mulheres pensam sobre o que seja "criar" seus cônjuges, no entanto, a ideia de rikú enquanto "estar junto" produzindo a conjugalidade, amansando uns aos outros, por assim dizer, parece ser produtiva para ambos os casos.

26 "Digamos então que a antropologia se distinga dos outros discursos sobre a socialidade humana não por dispor de uma doutrina particularmente sólida sobre a natureza das relações sociais, mas, ao contrário, por ter apenas uma vaga ideia inicial do que seja uma relação" (Viveiros de Castro 2002e:122).

27 “Toda essa maestria não é senão uma noção cosmológica que inflete sobre o plano sociopolítico" (Sztutman 2012:320), do parentesco inclusive. 
28 "Quando confrontados com as ideias e os conceitos de uma cultura concebida como outra, os antropólogos se deparam com a tarefa de inseri-las dentro de um universo conceitual que tem espaço para eles" (Strathern 1987:256 apud Corsín Jimenez \& Willerslev 2007:541, ênfase dos autores).

${ }^{29}$ Embora existam seres com pontos de vistas privilegiados (mas não absolutos), como os humanos e os ajỹ̃, como já observamos.

\section{Referências bibliográficas}

BALLÉ, William. 1994. Footprints of the forest$\mathrm{Ka}$ 'Apor Ethnobotany - the historical ecology of plant utilization by an Amazonian people (biology and resource management I). New York: Columbia University Press.

BATTAGLIA, Debbora. 1985. "We feed our father": paternal nurture among the Sabarl of Papua New Guinea". American Ethnologist, 2:427-41.

BONILLA, Oiara. 2005. “O bom patrão e o inimigo voraz: predação e comércio na cosmologia paumari". Mana. Estudos de Antropologia Social, 11(1):41-66.

CABRAL, Joana. 2012. Entre plantas e palavras. Modos de constituição de saberes entre os Wajãpi (AP). Tese de Doutorado, Universidade de São Paulo.

CARSTEN, Janet. 2000. "Introduction: cultures of relatedness". In: J. Cartsen (org.), Culture of relatedness. Cambridge: Cambridge University Press. pp. 01-36 CESARINO, Pedro de Niemeyer. 2010. “Donos e duplos: relações de conhecimento, propriedade e autoria entre os Marubo". Revista de Antropologia, 53(1):147-197.

COELHODE SOUZA, Marcela. 2004. "Parentes de sangue: incesto, substância e relação no pensamento Timbira". Mana. Estudos de Antropologia Social, 10(1):25-60.
CORMIER, Loretta. 2003. Kinship with monkeys - the Guajá foragers of eastern Amazonia (historical ecology series). New York: Columbia University Press. CORSÍN JIMENEZ, Alberto; WILLERSLEV, Rane. 2007. "An anthropological concept of the concept': reversibility among the Siberian Yukaghirs". Journal of the Royal Anthropological Institute (N.S.), 13:527-544.

DELEUZE, Gilles \& GUATTARI, Félix. 1992. O queé a filosofia? São Paulo: Editora 34. DESCOLA, Philippe. 1986. La nature domestique: symbolisme et praxis dans l'écologie des Achuar. Paris: Maison des Sciences de l'Homme.

_.2006. As lanças do crepúsculo: relações jívaro na alta Amazônia. São Paulo: Cosac Naify.

DOOLEY, Robert A. 1982. Vocabulário do Guarani. Brasília-DF: Summer Institute of Linguistics.

ERIKSON, Philippe. 1987. "De l'apprivoisement à l'approvisionnement: chasse, alliance et familiarisation en Amazonie amérindienne". Techniques et Cultures, 9:105-140. . 2012. "Animais demais". Anuário Antropológico 2011(II):15-32.

FAUSTO, Carlos. 1995. "De primos e sobrinhas: terminologia e aliança entre os 
Parakanã (Tupi) do Pará". In: Eduardo Viveiros de Castro (org.), Antropologia do parentesco - estudos ameríndios. Rio de Janeiro: Editora UFRJ. pp. 61-119. - 2001. Inimigos fiéis: história, guerra e xamanismo na Amazônia. São Paulo: Edusp.

. 2008. "Donos demais: maestria e domínio na Amazônia". Mana. Estudos de Antropologia Social, 14(2):329-366.

FERNANDES, Florestan. 1963 [1949]. A organização social dos Tupinambá. São Paulo: Difel.

FORLINE, Louis Carlos. 1997. The persistence and cultural transformation of the Guajá indians: foragers of Maranhão state, Brazil. Tese de Doutorado, University of Florida.

GALLOIS, Dominique. 1988. O movimento na cosmologia waiãpi: criação, expansão e transformação do mundo. Tese de Doutorado, Universidade de São Paulo.

GARCIA, Uirá. 2010. Karawara: a caça e o mundo dos Awá-Guajá. Tese de Doutorado, Universidade de São Paulo. - 2012a. "Ka'á Watá, 'andar na floresta': caça e território em um grupo tupi da Amazônia". Mediações - Revista de Ciências Sociais, 17(1):172-190.

- 2012b. "O funeral do caçador: caça e perigo na Amazônia". Anuário Antropológico, 2011(II):33-55.

GOW, Peter. 1991. Of mixed blood: kinship and history in Peruvian Amazonia. Oxford: Claredon Press.

_. 1997. "O parentesco como consciência humana". Mana. Estudos de Antropologia Social, 3(2):39- 66.

HUGH-JONES, Stephen. 1996. "Bonnes raisons ou mauvaise conscience? De l'ambivalence de certains amazoniens envers la consommation de viande". Terrain, 26:123-148.

HUXLEY, Francis. 1963. Selvagens amáveis - uma antropologia entre os índios Urubus do Brasil. São Paulo: Companhia Ed. Nacional.
KOHN, Eduardo. 2007. "Animal masters and the ecological embedding of history among the Ávila Runa of Ecuador". In: Carlos Fausto \& Michael Heckenberger (orgs.), Time and memory in indigenous Amazonia: anthropological perspectives. Gainesville: University Press of Florida. pp. 106-129.

LEA, Vanessa. 2012. Riquezas intangíveis de pessoas partíveis: os Mebêngôkre (Kayapó) do Brasil Central. São Paulo: Edusp. LÉVI-STRAUSS, Claude. 1982 [1967]. As estruturas elementares do parentesco. Petrópolis: Vozes.

LIMA, Tânia Stolze. 2005. Um peixe olhou pra mim - o povo Yudjá e a perspectiva. São Paulo: Editora da Unesp.

MAGALHÃES, Marina Maria. 2007. Sobre a morfologia e sintaxe da língua Guajá. Tese de Doutorado, Universidade de Brasília.

MULLER, Regina Polo. 1993. Os Asuriní do Xingu: história e arte. Campinas: Ed. Unicamp.

NEEDHAM, Rodney. 1971 [1967]. "Remarks on the analysis of kinship and marriage". In: R. Needham (org.), Rethinking kinship and marriage. London: Tavistock. pp. 01-34.

OVERING KAPLAN, Joanna. 1977. "Orientation for paper topics" \& "Comments". In: Joanna O. Faplan (org.), Social time and social space in Lowland South American societies, Actes du XLII Congrès International des Américanistes (Paris). pp. 9-10, 387-394. Mimeo. . 1999. "Elogio do cotidiano: a confiança e a arte da vida social em uma comunidade amazônica". Mana. Estudos de Antropologia Social, 5(1): 81-107.

RIVAL, Laura. 1998. "Androgynous parents and guest children: the Huaorani couvade". The Journal of the Royal Anthropological Institute, 4(4):619-642.

RIVIÈRE, Peter. 1969. Marriage among the Trio: a principle of social organisation. Oxford: Claredon Press. 
SAHLINS, Marshall. 2011. "What kinship is (part one)". JRAI (NS), 17:2-19; "What kinship is (part two)", JRAI (NS), 17:227-42.

SCHNEIDER, David M. 1965. "Some muddles in the models: or, how the system really works". In: M. Banton (ed.), The relevance of models for social anthropology. ASA Monographs 1. London: Tavistock Publications. pp. 25-86. (republicado em HAU: Journal of Ethnographic Theory, 1(1):451492, 2011).

1972. "What is kinship all about?". In: Priscilla Reining (ed.), Kinship studies in the Morgan centennial year. Washington, D.C.: The Anthtopological Society of Washington. pp. 32-63. (republicado em R. Parkin \& L. Stone. 2004. Kinship and family: an anthropological reader. Malden/Oxford: Blackwell.

- 1984. A critique of the study of kinship. Ann Arbor: University of Michigan.

SCHROEDER, Ivo. 2006. Política e parentesco nos Xerente. Tese de Doutorado, Universidade de São Paulo.

STRATHERN, Marilyn. 1995. The relation: issues in complexity and scale. Cambridge: Prickly Pear Press ("A relação: acerca da complexidade e da escala". 2014. In: O efeito etnográfico. São Paulo: Cosac Naify. pp. 263-294.

- 1992. After nature: English kinship im the late twentieth century. Cambridge: Cambridge University Press. - 1999. Property, substance and effect: anthropological essays on persons and things. London: The Athlone Press. - 2006 [1988]. O gênero da dádiva problemas com as mulheres e problemas com a sociedade na Melanésia. Campinas: Editora da Unicamp.

SZTUTMAN, Renato. 2012. O profeta e o principal. São Paulo: Edusp.

TAYLOR, Anne-Christine. 2001. "Wives, pets and affines: marriage among the Jivaro". In: L. M. Rival \& N. L. Whitehead (orgs.), Beyond the visible and the material: the ameriandianization of society in the work of Peter Rivière. Oxford: Oxford University Press. pp. 45-56.

TRAUTMANN, Thomas R. \& BARNES, R. H. 1998. "'Dravidian', 'Iroquois' and 'Crow-Omaha' in North American perspective". In: Maurice Godelier et al. (orgs.), Transformations of kinship. Washington: Smithsonian Institution Press. pp. 27-58.

VANDER VELDEN, Felipe. 2010. Inquietas companhias. Sobre os animais de criação entre os Karitiana. Tese de Doutorado, Unicamp.

VIVEIROS DE CASTRO, Eduardo. 1986. Araweté: os deuses canibais. Rio de Janeiro: Jorge Zahar/ Anpocs. . 2002a. "O problema da afinidade na Amazônia". In: A inconstância da alma selvagem e outros ensaios de antropologia. São Paulo: Cosac \& Naify. pp. 87-180.

. 2002b. "Multinaturalismo e perspectivismo na América indígena". In: A inconstância da alma selvagem e outros ensaios de antropologia. São Paulo: Cosac \& Naify. pp. 345-399. - 2002c. "Atualização e contraefetuação do virtual: o processo do parentesco". In: A inconstância da alma selvagem e outros ensaios de antropologia. São Paulo: Cosac \& Naify. pp. 401-456. . 2002d. "Esboço da cosmologia Yawalapití". In: A inconstância da alma selvagem e outros ensaios de antropologia. São Paulo: Cosac \& Naify. pp. 25-85.

. 2002e. "O nativo relativo". Mana. Estudos de Antropologia Social, 8(1):113-148. . 2003. After-dinner speech given at "Anthropology and Science", the 5th Decenial Conference of the Association of Social Anthropologists of Great Britain and Commonwealth 2003. Mimeo. 
2007. "Filiação intensiva e aliança demoníaca". Novos Estudos do Cebrap, 77:91-126.

2009. "The gift and the given: three nano-essays on kinship and magic". In: S. Bamford \& J. Leach (orgs.), Kinship and beyond: the genealogical model reconsidered. Nova York/ Oxford: Berghahn Books. pp. 237-268.

WAGNER, Roy. 1977. "Analogic kinship: a Daribi example". American Ethnologist, 4:623-642. 


\section{Resumo}

Este artigo é baseado em minha experiência de campo entre os Awá-Guajá, um pequeno grupo falante de uma variante do Tupi-Guarani, habitantes do extremo oriental da Amazônia brasileira. Em busca de uma definição etnográfica sobre o parentesco, o artigo se interessa por questões relativas à figura dos "donos" na Amazônia, propondo um diálogo com um dos aspectos menos abordados do tema, que é a relação deste com a conjugalidade. Argumento que, para os Guajá, relações recortadas como as do universo da "familiarização" e "maestria" são não apenas coextensivas ao campo do parentesco, como também revelam uma concepção muito particular do que seja a relação conjugal. O processo do parentesco awá-guajá, no qual o cônjuge é aquele que é transformado em um através de um sistema de ações bem particulares, só pode ser compreendido se, além do tema da afinidade na Amazônia, articularmos certos aspectos relativos à familiarização e à maestria.

Palavras-chave Awá-Guajá, Amazônia, Criação, Relação, Parentesco.

\section{Abstract}

This article is based on fieldwork among the Awa-Guajá people, a small indigenous group of Tupí-Guaraní speakers inhabiting the eastern portion of Brazil's Amazon region. Aiming for an ethnographic definition of kinship, this article engages in issues related to the figure of the "owners" in the Amazon, proposing a dialogue with a seldom discussed aspect of this subject, namely, its relation to conjugality. I argue that relationships included in the universe of "familiarity" and "mastery" are not only coextensive with the field of kinship; they also reveal a very particular conception of conjugality. The process of Awá-Guajá kinship, where the spouse is transformed through a very particular system of actions, can only be understood if we move beyond the issue of Amazonian affinity, and articulate it with certain aspects of the familiarity and mastery theme.

Key words Awá-Guajá, Amazon, Creating, Relation, Kinship. 